$911.3: 37.7$

\author{
$-2012$ \\ - тецюк \\ ьвівський н ціон льний університет імені в н \\ вул. . орошенк , 41, м. ьвів, 79000, кр їн
}

озглянуто основні н прями вдоскон лення тр нспортної системи ьвівської обл сті т м. ьвов для успішного проведення чемпіон ту з футболу у 2012 р., с ме: удоскон лення втомобільного, з лізничного т повітряного сполучення н території н шого регіону. ідповідно до держ вних прогр м, передб чено низку з ходів з розвитку різних видів тр нспорту т вдоскон лення тр нспортних мереж.

лючові слов : тр нспортн інфр структур , чемпіон т вропи з футболу, з лізничний тр нспорт, втомобільні шляхи, еропорт, міжн родні тр нспортні коридори.

роведення фін льної ч стини чемпіон ту вропи 2012 р. з футболу в кр їні є одним із в жливих євроінтегр ційних процесів, що поліпш ть імідж кр їни у міжн родному вимірі, т кож м тимуть вплив н поліпшення економічної ситу ції в кр їні, сприятимуть з лученню іноземних т внутрішніх інвестицій у в жливі г лузі економіки - будівництво, тр нспорт, сферу послуг, у тім числі туризм.

жливими вимог ми для орг ніз ції т проведення вро-2012 н території кр їни є створення необхідних умов із з безпечення розвитку інфр структури міст , яке прийм тиме гостей (тр нспортн систем, телекомунік ції, з кл ди охорони здоров'я тощо). озвиток дорожнього господ рств території м є зН чний вплив н туристичну прив бливість регіону.

еоретичною т методологічною основою суспільно-геогр фічних досліджень тр нспортної інфр структури кр їни т з хідного регіону зокрем є пр ці укр їнських геогр фів, . оліков , . он к , . ригорович , . орошенк , . ст вного, . оценко, . уцишин , . цях , . ис ренко, . істун , . уденк , . опчієв , . блія.

ш мет - окреслити основні н прями т проблеми, пов'яз ні з модерніз цією втодоріг, з лізничних шляхів т ві ційного тр нспорту н території ьвівської обл. т м. ьвов в контексті підготовки до проведення у 2012 р. н території кр їни і ольщі чемпіон ту вропи з футболу.

мовою проведення фін льної ч стини чемпіон ту вропи з футболу у 2012 р. в кр їні, поряд з мережею комфорт бельних з кл дів готельного господ рств т новозбудов ним суч сно обл дн ним ст діоном, новими тренув льними полями, є розвинут дорожньо-тр нспортн інфр структур .

оловні з вд ння стр тегії перспективного розвитку дорожнього господ рств ьвівської обл. н н йближчі роки формуються з ур хув нням з ходів із розбудови дорожньо-тр нспортної мережі до підготовки чемпіон ту вропи з футболу 2012 р., що

(C) тецюк ., 2011 
передб ч є модерніз цію втодоріг, з лізничних шляхів т н л годження ві ційного тр нспорту.

обл сті ре лізують егіон льну прогр му з підготовки т проведення у м. ьвові “ вро-2012”. я прогр м визн ч є увесь комплекс 3 вд нь т проектів, 3 пл нов них до ре ліз ції в р мк х підготовки обл сті до фін льних зм Г нь чемпіон ту вропи 3 футболу. дними із н йм сшт бніших інвестиційних проектів цієї прогр ми є розбудов тр нспортної інфр структури, с ме:

- реконструкція митних переходів ( егині- едик , в - уськ - ребенне, р ковець- орчов );

- будівництво нових переходів н польській стороні ( удомєж- рушів, олгобичувгринів);

- реконструкція т будівництво тр нспортних коридорів і доріг ( $\mathrm{p}$ ковець- ьвівроди, в - уськ - овкв - ьвів, егині- ьвів);

- реконструкція міжн родних і з г льнодерж вних тр нспортних вузлів (реконструкція міжн родного еропорту “ ьвів”, будівництво т реконструкція комун льних доріг м. ьвов й втост нцій міст );

- реорг ніз ція системи місцевого тр нспортного сполучення, комун льного тр нспорту, стоянок т іншої внутрішньої тр нспортної інфр структури ьвов [7].

прогноз ми ф хівців, у період проведення вро-2012 ьвів і обл сть відвід ють близько 10 млн туристів т вболів льників [9]. ме тому н л годження ефективної системи перевезень є н дзвич йно в жливим.

ьвівщин розт шов н н перехресті б г тьох в жливих тр нспортних м гістр лей. ут густ мереж 3 лізничних, втомобільних 3 г льнообл сного, 3 г льнодерж вного і міжн родного зн чення доріг.

гоме місце у перевезенні п с жирів і в нт жів посід є 3 лізничний тр нспорт. овжин 3 лізничних колій 3 г льного користув ння у ьвівській обл. ст новить 1279,7 км, тобто 5,9 \% з лізничних колій кр їни, 3 густотою $з$ лізниць поступ ється лише онецькій обл. [10, с. 112]. ільш ч стин території відд лен від з лізниці менше ніж н 10 км. йбільшими з лізничними вузл ми є ьвів, p сне, трий.

йже 800 км дільниць ьвівської з лізниці входять до скл ду міжн родних тр нспортних коридорів: рітський № 3 ( ерлін- роцл в- еремишль- остиськ - ввів$p$ сне- ідволочиськ- озятин- иїв); рітський № 5 ( рієст- юблян - уд пешт- опввів), т кож міжн родний тр нспортний коридор д нськ ( лтійське море)- дес ( орне море) (н відтинку годин- овель- долбунів) [9].

обре з безпечен обл сть і втомобільними шлях ми. кщо в середньому по кp їні густот шляхів ст новить 275 км, то н ьвівщині - 375 км н $1000 \mathrm{kM}^{2}$. більш н ближеними до європейських ст нд ртів $є$ втомобільні дороги 3 г льнодерж вного зн чення першої к тегорії (з чотирм і більше смуг ми руху т шириною проїзної ч стини пон д 15 м), які в обл сті ст новлять усього 0,6 \% від протяжності доріг 3 твердим покриттям, т кож дороги другої к тегорії-11,3 \% [10, с. 112].

рив є підготовк з лізничного тр нспорту до проведення в кр їні вро-2012.

“ ьвівськ 3 лізниця” є в жливим елементом у тр нспортних перевезеннях між ходом т хідною вропою, оскільки межує 3 ольщею, горщиною, умунією, лов ччиною. е спонук є не лише до поліпшення орг ніз ції перевезень, підвищення швидкості перед чі в гонів, й відкриття нових прикордонних переходів. с мперед продовжув тимуться роботи, пов’яз ні з модерніз цією т реконструкцією з лізничних 
колій т іншої інфр структури. ля зручності спожив чів створен систем бронюв ння т прод жуз лізничних квитків через нтернет.

же близько десяти років існує проект продовження колії європейського зр зК (ширин 1435 мм) 3 еремишля до ьвов (н дільниці ьвів- остиськ - едик протяжністю 84 км) т под льше продовження колії до ернівців і виведення н румунську тр нспортну мережу, що д сть змогу створити у ьвові великий комплекс із обробки в нт жів т пришвидшити рух поїздів н ьвівській з лізниці [9]. роте б г то ф хівців т експертів ув ж є цей проект економічно невигідним і н віть шкідливим для тр нспортної системи кр їни.

ьогодні не лише проводять поточний ремонт колій ьвівської з лізниці, т кож будують нові з лізничні шляхи і н віть впров джують м сшт бні проекти, н прикл д, пл ни реконструкції ескидського тунелю т побудови нового тунелю, що позитивно вплине н 3 г льну пропускну зд тність міжн родного тр нспортного коридору т ліяловенія- горщин - лов ччин - кр їн [9].

удівництво нового тунелю $з$ мість в рійного н ділянці “ ескидсько- кот рське” у н прямі іжн родного тр нспортного коридору № 5 сприятиме збільшенню тр нзитних потоків у н прямі вроп - зія.

сновними тр нзитно-туристичними осями обл сті є міжн родні втом гістр лі -5 ( иїв- ьвів- ісс бон), -17 ( ьвів- юблін- рш в ), -40 ( ьвів- р ків- р нкфурт), -471 ( ьвів- трий- оп) [6].

ме під ч с вро-2012 можн буде повністю використ ти перев ги міжн родних тр нспортних коридорів: безперешкодний рух п с жирів і тов рів, підвищення пріоритетності тр нспортних шляхів, спрощені митні процедури т ін. озвиток втодорожнього комплексу зумовлює зрост ння придорожнього сервісу: збільшується кількість , п ркінгів, готелів, рестор нів т інших об'єктів.

одноч с мереж міжн родних доріг обл сті скл д ється 3 двох м гістр лей, що не відповід ють європейським ст нд рт м щодо б г тьох пок зників, зокрем , т ких, як низьк пропускн спроможність м гістр лей, м ло втошляхів 3 двом, трьом смуг ми руху, якість дорожнього покриття, н в нт ження н вісь, що лімітов н м сою до 38 т, 3 безпеченість суч сними дорожніми зн к ми і розміткою, необхідною кількістю пунктів технічної т медичної допомоги, х рчув ння т відпочинку, з пр вки п льним і м стилом, телефонного зв'язку. ід ч с будівництв нових втомобільних м гістр лей у системі тр нспортних коридорів ці всі пок зники повинні бути узгоджені з європейськими ст нд рт ми.

3 хідному кордоні ьвівщини є низк міждерж вних переходів, що з'єднують кр їну з ольщею, це втомобільні тр нскордонні переходи в - уськ ( овківський p-н), p ковець ( ворівський р-н), егині ( остиський p-н); з лізничні - дв у ві- уській ( овківський р-н), остиськ ( остиський p-н), мільниця ( т рос мбірський р-н). три переходи спрощеного пропуску ж нковичі т мільниця ( $\mathrm{T}$ рос мбірського р-ну).

вирішенні проблем функціонув ння прикордонної тр нспортної інфр структури в жливим є розвиток мережі втомобільних доріг з г льного користув ння н підход $\mathrm{x}$ до н явних і новостворених пунктів пропуску через держ вний кордон, с ме: к піт льні ремонти н дорог х держ вного зн чення - -09 ьвів- в - уськ , ьвів- егині, ьвів- р ковець; будівництво підходів до міжн родних пунктів пропуску н дорог х місцевого зн чення - до “иж нковичі- ільховіце”, “рушівудомеж”, реконструкція втодороги “мільниця- т рий мбір”. 
рив є робот з уведення в експлу т цію до вро-2012 нових пунктів пропуску, зокрем, у урківському, т рос мбірському, ок льському р йон х:

“ оберк - мольник” ориня- оберк держ вний кордон урківського р-ну;

- “ ш нець- истре” держ вний кордон- ш нець- трілки т рос мбірсь-

кого р-ну;

- “ елз- удинін” держ вний кордон- болоття- елз- еликі ости ок льського р-ну [6].

ерспективними н прям ми розвитку ві тр нспорту обл сті є модерніз ція інфр структури львівського летовищ і відкриття нових ві ліній.

езв ж ючи н те, що ві ційний тр нспорт уже близько ст років функціонує н території м. ьвов , його розвиток пов'яз ний з низкою проблем т перспектив.

н чні обсяги будівельних робіт в ві ційній г лузі пл нують провести до 2012 р. о чемпіон ту з футболу буде збільшено кількість ві рейсів, оновлено ві п рк, підвищено пропускну спроможність еропорту, т кож рівень сервісу. дним із в жливих летовищ чемпіон ту буде еропорт м. ьвов, резервними - в в но- $p$ нківську т уцьку.

2009 р. розпоч то роботи зі спорудження нового п с жирського еровокз лу, у тому числі нового п с жирського термін лу (пропускн спроможність - 1000 осіб з год, площ - $39000 \mathrm{~m}^{2}$ ), при еровокз льної площі з будівництвом нової втост нції т п ркінгу. ередб чено т кож н 500 м продовжити злітно-пос дкову смугу; переобл дн ти готель “ уст нь”, збільшивши його ємність до 500 місць, обл штув ти бізнесцентр, центр відпочинку тощо. і роботи пл нують з вершити до 30 жовтня 2011 р. [4]. ісля з вершення цих робіт еропорт у ьвові прийм тиме повітряні судн м йже всіх типів т зможе з безпечити польоти пр ктично у всі ч стини світу.

2010 р. відкрито три нові міжн родні рейси, що з'єдн ли ьвів 3 ондоном, ортмундом т юнхеном.

исок шільність втодорожньої мережі сприяє охопленню кільцевими екскурсійнотуристичними м ршрут ми більшості природних т історико-культурних тр кцій обл сті. ині вздовж втошляхів міжн родного і регіон льного зн чення, що їх ктивно використовують туристи, формується розг лужен інфр структур прив тних мотелів, кемпінгів, рестор нів, сервіс-центрів, що обслуговують тр нзитно-туристичні потоки. ротяжність втомобільних доріг 3 г льного користув ння ьвівської обл. ст новить 8 373,7 км, з них:

- втомобільні дороги держ вного зн чення - 1 039,2 км, у тому числі міжн родні 547,9 км; н ціон льні - 342,8 км; регіон льні - 1 48,5 км;

- втомобільні дороги місцевого зн чення - 7334,5 км, у тому числі територі льні 1 036,1 км; обл сні - 612,2 км; р йонні - 5 686,2 км [6].

ідповідно до ерж вної прогр ми розвитку втомобільних доріг з г льного користув ння н 2007-2011 pр. розроблено пл ни щодо к піт льного ремонту н явних доріг т побудови нових, зокрем концесійної дороги ьвів- р ковець (довжиною 84,4 км) [2].

ісля введення 1998 р. в експлу т цію суч сного митного пункту пропуску р ковець 3 пл нов но будівництво концесійної втодороги р ковець- ьвів- роди- івне. уч сний митний втоперехід р ковець з пропускною зд тністю 5000 в нт жних втомобілів $з$ добу є одним 3 н йбільших в кр їні. одноч с втомобільн дорог -10 ьвів- р ковець 3 х р ктеристик ми не з довольняє вимог щодо пропускної зд тності т якісних умов тр нспортного руху. 
окрем , оскільки ділянк івне- иїв втом гістр лі -06 м є тр нспортно-експлут ційні х р ктеристики першої к тегорії і є однією 3 н йкр щих втодоріг в кр їні, то ре ліз ція проектів будівництв й експлу т ції нових концесійних втодоріг ьвівр ковець, ьвів- роди (очікув ні терміни введення в експлу т цію по черг $\mathrm{x}-2008$ 2010 рр.) т успішне просув ння проекту будівництв нової втодо-роги роди- івне д дуть змогу з безпечити відмінні умови втотр нспортного сполу-чення н всій ч стині №3 н території кр їни. озбудов №3 у ч стині втотр нспортного сполучення н території ольщі відбув ється шляхом реконструкції т будівництв втодоріг н відрізку роцл в- p ків- орчов / p ковець і з г лом швидко. ьогодні $з$ держ вні кошти вже побудов но дві ділянки нової втодороги: н північному обході м. ьвов $(2,1$ км) й обході смт р ковець $(6,0$ км). і ділянки м ють другу к тегорію [6].

ідповідно до держ вної стр тегії розвитку мережі втомобільних доріг і прогр ми створення т функціонув ння н ціон льної мережі міжн родних тр нспортних коридорів в кр їні проект ре лізують як пілотний у $\mathrm{p}$ мК $\mathrm{x}$ розбудови міжн родного тр нспортного коридору №3 ерлін/ резден- роцл в- ьвів- иїв [1].

орогу ьвів- р ківець пл нують будув ти в три ет пи. ерший ет п - побудов ділянки р ковець- ворів (20,3 км), другий - спорудження тр си н відтинку ворівьвів (40,1 км), третій - будівництво північного обходу м. ьвов $(23,9$ км). озр хунков швидкість руху н цій дорозі буде ст новити 150 км/год, к тегорія дороги - перш . орм тивний термін будівництв об'єкт концесії -5 років, термін концесії - 45 років, прогнозов ний термін окупності проекту - 15 років [6].

сновним проблемним пит нням под льшого просув ння проекту є з безпечення повного фін нсув ння інвестиційних витр т н створення об'єКт концесії т ухв лення рішень н з конод вчому рівні стосовно г р нтій досягнення фін нсової окупності інвестицій у р мк х проекту.

о першочергових об'єктів нового будівництв у ьвівській обл. н леж ть об'їзн дорог м. трий, -09 ьвів- в - уськ , -02 ьвів- ернопіль, -11 ьвів- егині, “ оберк - мольник”, “ш нець- истре”, “елз- удинін” (з г льн протяжність - 162 км) [6].

процесі розробки перебув є тр нспортн концепція ьвов н н йближчі 20 років, для цього у 2009 р. рядовий 6 нк імеччини KFW н д в ьвову гр нТ у сумі 500 тис. євро. сновною скл довою концепції є підготовк тр нспортної інфр структури міст до вро-2012. іськ р д м. ьвов розробил проект л ну мобільності м. ьвов під ч с підготовки т проведення в кр їні фін льної ч стини чемпіон ту вропи 2012 p. з футболу [5].

озроблен систем моніторингу міст - це в жливий ет п перед впров дженням опер ційного пл нув ння тр нспортної концепції ьвов . о системи моніторингу ввійшли з г льні н прями у місті - упр вління тр нспортом н період турніру т тр нспортн інфр структур міст з г лом, опер ційні компоненти тр нспортного обслуговув ння вро-2012 - орг ніз ція т упр вління тр нспортним з безпеченням ст діону (“ост нній кілометр”), тр нспортно-перес дковий вузол в еропорту т тр нспортні сполучення: еропорт - центр, еропорт - ст діон, т кож упр вління тр нспортом у спеці льних зон х - сполучення відд леного розміщення, допоміжного еропорту т міст , що прийм $\epsilon$, i, звич йно, тр нспортне з безпечення ф н-зони [5].

творення суч сної системи для з безпечення н д ння послуг гром дського тр нспорту м. ьвов передб ч є оновлення п рку тр мв йних в гонів, будівництво т ре- 
конструкцію тр мв йних і тролейбусних ліній; будівництво, реконструкцію т ремонт втомобільних доріг комун льної вл сності, оновлення п рку міських втобусів н умов х фін нсового лізингу. дзвич йно в жливим $є$ н л годження безперебійного тр нспортного сполучення між ст діоном т об’єКТ ми туристичної інфр структури. $і$ і ходи будуть ре лізов ні головно з кошти держ вного т міського бюджету ьвов .

p мк х цієї стр тегії з пропонов но т прор хов но декільк проектів розв нт ження центр льної ч стини міст, вирішення проблеми з торів т перекриття доріг, розроблено концепцію прокл д ння тр мв йної колії н ихів [11].

тже, для успішної підготовки т проведення у ьвівській обл. т $\quad$ кр їні фін льної ч стини чемпіон ту вропи 2012 р. з футболу т функціонув ння тр нспортних потоків н території обл сті т обл сного центру необхідно:

створити низку нових точкових елементів тр нспортної інфр структури, т ких як пункти втомобільного сервісу т прикордонні пункти пропуску; поліпшити інформ ційне з безпечення уч сників дорожнього руху;

розширити мережу міжн родних тр нспортних коридорів т міжрегіон льних втошляхів;

модернізув ти інфр структуру еропорту м. ьвов, підвищити його пропускну спроможність, відкрити нові ві лінії;

створити суч сну систему гром дського тр нспорту у ьвові.

1. онцепція створення т функціонув ння н ціон льної мережі міжн родних тр нспортних коридорів в кр їні. ост нов від 4 серпня 1997 р. № 821 [ лектронний ресурс]. ежим доступу : http://zakon1.rada.gov.ua/cgi-bin/laws/main.cgi?nreg=821-97-\%EF

2. ро внесення змін до ерж вної прогр ми розвитку втомобільних доріг з г льного користув ння н 2007-2011 роки. ост нов кр їни від 15.09.2008. № 67, 2008 р. . 16.

3. ро з твердження ерж вної цільової прогр ми підготовки т проведення в кр їні фін льної ч стини чемпіон ту вропи 2012 року з футболу. ост нов від 14 квітня 2010 р. № 357 // фіційний вісник кр їни від 04.06.2010. № 39. 2010. . . 44-62.

4. нформ ційний центр вро-2012 - кр їн [ лектронний ресурс].

ежим доступу : http://www.mfa.gov.ua/australia/ua/publication/content/28696.htm

5. іський тр нспорт [ лектронний ресурс].

ежим доступу : http://www.city-adm.lviv.ua/euro-2012/transport/transportation

6. ервинні м тері ли головного упр вління промисловості т розвитку інфр структури ьвівської обл сної держ вної дміністр ції., 2010.45 с.

7. ідготовк до вро- 2012 н ьвівщині [ лектронний ресурс]. ежим доступу : http://www.loda.gov.ua/ua/priorities/2012/preparation/

8. л н мобільності м. ьвов під ч с підготовки т проведення в кр їні фін льної ч стини чемпіон ту вропи 2012 року з футболу (проект) [ лектронний ресурс].

ежим доступу : http://www.city-adm.lviv.ua/lmrdownloads/evro2012/transport_concept.pdf

9. т н підготовки до проведення в кр їні фін льної ч стини чемпіон ту вропи 2012 року з футболу [ лектронний ресурс]. ежим доступу : http://www.mintrans.gov.ua/uk/category/euro.html 10. тр тегія розвитку ьвівської обл сті до 2012 року. кономік . успільство. ередовище. ип. 8. ьвів : оловне упр вління ст тистики у ьвівській обл сті, 2009. 284 с.

11. ьогодні довий предст вить у льцбурзі проект будівництв вроколії до ьвов [ лектронний ресурс]. ежим доступу : http://www.vgolos.com.ua/politic/1108.html?page=119

12. крз лізниця продовжує готув ти об'єкти до вро-2012 [ лектронний ресурс]. ежим доступу : http://www.uz.gov.ua/?f=Doc.View\&p=news_5515.0 


\title{
DEVELOPMENT OF TRANSPORT INFRASTRUCTURE IN LVIV REGION FOR EUROPEAN CHAMPIONSHIPS IN 2012
}

\author{
O. Stetsyuk \\ Ivan Franko National University of Lviv, \\ P. Doroshenko St., 41, UA - 79000 Lviv, Ukraine, tel. (0322) 394-769
}

In this article the author examines the main directions of improving the transport system of Lviv region and Lviv for the success of the European Championship in 2012, such as: improving road, rail and air traffic in our region. According to the government programs are planned activities for the development of different modes of transport and improving transport networks.

Key words: transport infrastructure, European Championships, railway transport, railways, highways, airports, international transport corridors.

\section{$-2012$}

- тецюк

ввовский н цион льный университет имени в н $p$ нко,
ул. . орошенко, 41, г. ввов, 79000, кр ин, тел. (0322) 394-769

зложено гл вные н пр вления усовершенствов ния тр нспортной системы ьвовской обл. и г. ьвов для успешного проведения чемпион т по футболу в 2012 г., именно: улучшение втомобильного, железнодорожного и воздушного сообщения н территории н шего регион . огл сно с госуд рственными прогр мм ми, предусмотрено ряд действий по р звитию $\mathrm{p}$ зличных видов тр нспорт и усовершенствов нию тр нспортных сетей.

лючевые слов : тр нспортн я инфр структур, чемпион т вропы по футболу, железнодорожный тр нспорт, втомобильные пути, эропорт, междун родные тр нспортные коридоры.

т ття н дійшл до редколегії 01.04.2011 рийнят до друку 19.04.2011 